\title{
Customer Loyalty to Modern Retail Channel A Study in The Context of Covid-19 Pandemic in Vietnam
}

\section{Bui Thi HIEN ${ }^{1}$, Nguyen Thi Ngoc TRAM ${ }^{2}$, Tran Nguyen MINH Al ${ }^{3}$}

\author{
1,2,3 Department of Business Administration, Industrial University of Ho Chi Minh City, No. 12 Nguyen Van Bao Street, Ward \\ 4, Go Vap District, Ho Chi Minh City, Viet Nam. \\ Email: buithihien@iuh.edu.vn¹, nguyenthingoctram@iuh.edu.vn², trannguyenminhai@iuh.edu.vn³
}

\author{
Received: 05.06.2021 Accepted: 15.08.2021 Published: 24.10.2021 $\quad$ DOI: 10.47750/QAS/22.184.16
}

\begin{abstract}
This study was conducted for the purpose of maintaining the sustainable loyalty of customers towards modern retail channel in the context of the Covid-19 pandemic. The data used in the study were collected from 215 customers who went shopping at convenience stores, mini-marts and others made purchase by means of online shopping via the supermarkets' websites during the Covid-19 pandemic in Vietnam. The result shows that there are five (5) factors positively affecting customers' loyalty including perceived value, trust, service quality, personality traits, and commitment, among which perceived value has the strongest impact on customer loyalty. In addition, the study also shows that the switching cost factor moderates the relationship between customer trust and loyalty. Based on the result, the study proposes a number of managerial implications for the managers of modern retail channel from which to have suitable business methods and marketing strategies to meet the requirements of different types of customers, thereby increasing customer loyalty, gaining competitive advantage, and bringing sustainable business performance to businesses during the new normal and post-pandemic period.
\end{abstract}

Keywords: customer loyalty; perceived value; customer trust; switching cost; personality traits; modern retail channel.

\section{Introduction}

The Covid-19 pandemic at an alarming rate has brought a massive global economic shock, leading to a sharp recession in many countries. The base forecast from World Bank narrowed the global GDP to $5.2 \%$ by 2020 - the deepest level of global recession in eight decades (World Bank, 2020, page 4). Despite the unprecedented support policies, with the exception of East Asia, most countries in other regions forecast negative economic growth in 2020 and the global economy is expected to plummet $-3 \%$ by 2020 (IMF 2020), much worse than it was during the 2008-2009 financial crisis. Those are the warnings about the global economic downturn due to Covid-19. In the spiral of economic slowdown, the global retail market has inherently slowed its growth rate (from $22.9 \%$ in 2018 and $20.7 \%$ in 2019 , the growth rate is forecasted to decline to $19 \%$ in 2020) (Lipsman, A. (2019) due to the decline in consumer spending in the past two years which reflects the growing economic uncertainty and a declining economic environment in many parts of the world. At present, with the strong effect of Covid-19, the total retail worldwide revenue is expected to reach $\$ 23,358$ trillion by 2020 , down $5.7 \%$ from 2019 and nearly $12 \%$ lower than previous estimates prior to the pandemic of $\$ 26,459$ trillion dollars (Ethan Cramer-Flood. (2020).

Relevant study on customer loyalty can be approached from different angles such as the relationship between customer loyalty and social responsibility (Stanisavljević, 2017), or the service quality affecting the loyalty in modern retail channel (Orel \& Kara, 2014. Recent studies on loyalty examine the moderating role of happiness in the relationship between customer satisfaction and customer loyalty for a particular industry in the overall retail sector (Zhong \& Moon, 2020). The next study (Menidjel et al. 2020) focuses on the impacts of personality on consumers' perceptions of relationship investment and the process of building loyalty in the context of retailing. This study is different from previous studies because it claimed that customer personality traits is a factor that directly impacts customer loyalty. Besides this study also considers switching costs in the role of relationship moderator between trust, perceived value, service quality versus customer loyalty within modern retail channels while other studies are often focused in the banking sector (Rahi \& Ghani, 2016) or followed a specific retail sector (Singh \& Rosengren, 2020; Harazneh et al. 2020) or across all general retail channels.

This study will provide contributions to the existing research with two specific goals. First, this study proposes and examines a comprehensive model that provides an understanding of how the factors affect customer loyalty to the modern retail channels in the context of Covid-19 causing shock to loyalty. Second, this study fills an important gap in the literature by exploring the moderating role of the switching costs between perceived value, customer trust, and service quality versus customer loyalty within modern retail channels.

This study is organized into three sections. The first part presents theoretical background and hypothesis development. The next section describes the research methodology and empirical results. The findings, management implications, limitations, and future research directions will be discussed in the final section. 


\section{Theory Background And Research Framework \\ Customer loyalty}

Customer loyalty can be considered as one of the key measurements for the success of different businesses in the market (Nyadzayo \& Khajehzadeh, 2016); the cost of acquiring a new customer is much more than maintaining an existing one. Loyal customers encourage others to purchase from your business and think more before considering other services (Obi, 2020). According to Cossío-Silva et al. (2016), customer loyalty is one of the best intangible assets an organization can have and a source of competitive advantage with huge differences. Therefore, customer loyalty is still attracting the attention of scholars due to its explicit meaning and the sustainable values it brings to an organization.

Existing literature in customer loyalty indicate that it is a complex and multidimensional structure, without a unique definition. The best definition must be based on the objective, context, and research area. Some definitions are based on the perspective of customer behaviors (Thaichon \& Jebarajakirthy, 2015) or through their attitudes (Jaiswal \& Niraj, 2011; Thakur, 2016; Song et al., 2019). However, recent studies approach and measure customer loyalty in terms of both behaviors and attitudes (Curran et al., 2010; Suhartanto, 2019). They argue that studying customer loyalty from a behavioral perspective alone may lead to inaccurate evaluatation of loyalty due to the limitations in distinguishing between commitment and convenience or it is possible that repetitive purchases are caused by situational constraints such as high switching costs (Kandampully et al. 2015).

There are different existing definitions of customer loyalty such as ones from Casidy \& Wymer (2016) or Thakur (2016); however, the most widely applicable definition is from Oliver (1999): "Loyalty is described here as a deeply held commitment to rebuy or repatronize a preferred product/service consistently in the future, thus causing repetitive same-brand or same brandset purchasing, despite situational and marketing efforts having the potential to cause switching behavior." This study used the above definition as a guidance for analyzing the factors that affect customer loyalty to modern retail channels in the context of Covid-19 which causes loyalty shock.

\section{Perceived value and Customer loyalty}

Perceived value is defined as customer's evaluation of the cost of a product or service versus the benefits obtained from the product or service, especially in comparison with its peers (Ramadhan \& Yolanda Masnita Siagian, 2019). A company creates values when it designs and promotes its products to the potential customers; the customers then evaluate perceived value of the company's products versus its competitors to make consumption decisions (Jamrozy \& Lawonk, 2017). Therefore, the perceived value of the customers is one of the main factors contributing to the purchase intent because the higher perceived value of the service provider will result in the purchase intent and the product or service patronage and by delivering the value to the customers, the company can acquire loyal customers who can increase the purchase frequency and volume, and avoid customer behavioral conversion (Rust et al., 2004). The above studies have shown that the perceived value of the customers is the direct path and a significant factor affecting customer loyalty (Tu \& Chih, 2011; Baek et al. 2020). Therefore, the first hypothesis of this study is:

$\mathrm{H} 1$ : The perceived value of customers positively affects the modern retail channels customer loyalty.

\section{Customer trust and Customer loyalty}

Customer trust has a positive and significant impact on loyalty (Rico et al. 2019). There is a correlation between a trust in the seller, the store's confidence and the repetitive purchase (Bobâlcă, 2014). Trust is often seen as an intrinsic feature of valuable social interactions originating from personal relationships, a psychological state that helps develop long-term relationships and provides a basis for growing customer loyalty (Melewar et al., 2017). When potential customers develop the trust for the service provider, it has the potential to limit the risks of the purchasing process (Taylor et al. 2004) and allows the feeling of trust to emerge (Esenyel \& Girgen, 2019); thus, trust is the source of loyalty. Therefore, the next hypothesis of this study is:

$\mathrm{H} 2$ : Customer trust has a positive impact on the modern retail channels 'customer loyalty.

\section{Service quality and Customer loyalty}

An analysis from Alam \& Noor (2020) shows that the service quality is considered an important prediction of customer loyalty as it has a positive effect on customer retention; thus is closely related to profitability (Fornell, 1992). The previous studies emphasize that as service quality increases, customer satisfaction and customer loyalty also increase (Kaura et al. 2015; Fida et al. 2020). Particularly in the retail sector, many studies also identified the important role of service quality in determining the long-term customer engagement with a store (Yoon \& Park, 2018). The conclusion of Sivapalan \& Jebarajakirthy (2017) research stated that maintaining a higher quality of service in the supermarkets enhances customers's repetitive purchase intent and the long-term relationship with them, making them less likely to switch to competitors. From the previous research results, the next hypothesis is proposed as follow:

H3: Service quality has a positive impact on the modern retail channels' customer loyalty.

\section{Personality traits and Customer loyalty}

Personalities are "the psychological qualities that contribute to an individual's enduring and distinctive patterns of feeling, thinking and behaving" (Cervone \& Pervin, 2015). Personality traits influence the way customers evaluate the provided services and respond to the marketing strategies (Adjei \& Clark, 2010). Studies of consumer behavior have shown that characteristics can help develop the integrated conceptual frameworks for understanding the consumers and enable the development of better targeted communications (Baumgartner, 2002) as well as the most influential and relevant characteristics of consumers' conversion behavior (De Wulf et al. 2001). When a customer appreciates a certain brand and makes repetitive purchase from that brand due to the favorable traits that suit the customer's characteristics, he or she will have a positive image of that brand and is more likely to become a loyal customer (Kim et al. 2018; Elfergany \& Adl, 2020; Singh et al. 2020). Previous studies have shown a strong relationship between customer loyalty and characteristics.

Because previous studies of consumer behavior have shown that consumers cannot clearly differentiate their personality traits (Vázquez-Carrasco \& Foxall, 2006), the goal of this study is to identify the overall personality traits that most influence consumer behavior and are more likely to be brand loyalty (Kim et al. 2018). From the above theories, the next hypothesis proposed for this study is:

$\mathrm{H} 4$ : The overall personality traits of the customers have a positive impact on the modern retail channels' customer loyalty. 


\section{Commitment and Customer loyalty}

The organizational commitment is an individual's psychological attachment to the organization (Gruen et al. 2000) and is seen as important premise and has the strongest impact (Bloemer \& Odekerken-Schröder, 2002) to the customer loyalty. $\mathrm{Ng}$ et al. (2011) found that the growing benefits from the relationship between the commitment and the customer loyalty can increase the commitment and thereby, significantly improve the loyalty. Studies that approached brand loyalty suggest that brand loyalty appears to be interrelated with the purchase repetition (Song et al. 2019); while for retail services, Lee et al. (2007) concludes that the brand trust and the continued commitment are the main drivers for the brand loyalty. When a customer has a higher brand commitment, it can help to increase his brand loyalty (Hidayanti \& Nuryakin, 2018). These structures are the keys to develop the brand loyalty in the retail service industry and are a source of significant competitive advantage. Based on the above evidence, the next hypothesis of this study is:

H5: The customer commitment has a positive impact on the modern retail channels' customer loyalty.

\section{Switching Cost and Customer loyalty}

In marketing terms, especially from a customer loyalty perspective, switching costs are the costs that consumers incur as a result of changing the brands, suppliers, or service providers (Lee et al. 2001). High switching costs could be the factor preventing loyal customers from switching to another supplier or service provider, despite their dissatisfaction with the products or services (Saeed \& Siddiqui, 2016). Switching costs are not only economic (Morgan \& Hunt, 1994) but can also be also psychological and emotional (Sharma \& Patterson, 2000). The best switching cost can lead to repetitive purchase when the switching cost to an alternative supplier is deemed too high (Dick \& Basu, 1994); thus, it has a direct impact on the customer loyalty (Akbar, 2013). Previous studies have shown that switching cost might have a moderating effect in the perceived value of a customer in regards to the customer loyalty (Rahi \& Ghani, 2016) and it can play the moderating role in the perceived value-customer loyalty relationship only when the perceived value of the customer is above average (Yang \& Peterson, 2004). Simultaneously, switching costs can also have a moderating effect on the relationship between customer trust and loyalty, and the increase in switching costs have a direct impact on the relationship between customer trust and loyalty (Sharma \& Patterson, 2000). The latest study by Harazneh et al. (2020) claims that switching costs have positively and significantly improved the relationship of service quality with customer loyalty.

Based on the researched evidence, the proposed hypotheses are as follows.

H6: The interactive relationship between switching cost and perceived value has a positive impact on customer loyalty.

$\mathrm{H} 7$ : The interactive relationship between switching cost and customer trust has a positive impact on customer loyalty.

H8: The interactive relationship between switching cost and service quality has a positive impact on customer loyalty.

\section{Conceptual framework}

This model presents the conceptual framework that guides our research efforts. Based on previous relevant research, the model determines perceived value, trust, service quality, personality traits, and commitment as the factors that directly affect customer loyalty for modern retail channels. At the same time, the model also proposes the switching cost hypothesis that regulates the relationship between customer loyalty with perceived value, trust, and service quality.

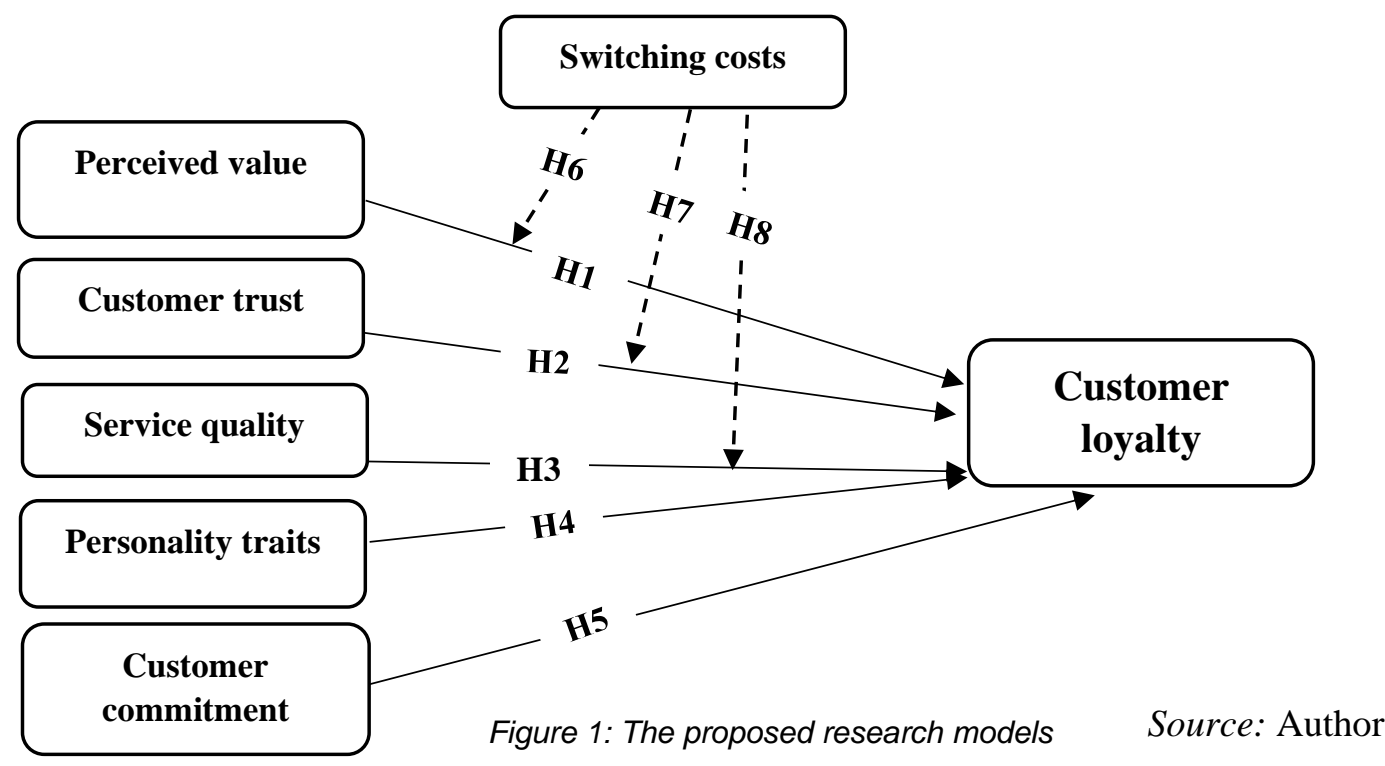

\section{Research Methodology}

\section{Research progress}

The research was conduct through two phases:

Phase 1: After the scales were Vietnamized and edited, in order to screen and select the appropriate scales for the context, an in-depth interview with 5 professors with expertise in research methodology and service marketing was conducted (Thakur, 2016). The research team also consulted 10 managers and employees of the modern retail channels to ensure the reliability and validity of the scales. Then, the research team conducted a preliminary survey with 50 customers of the modern retail channels to check the suitability of the scales. 


\section{GENERAL MANAGEMENT}

Phase 2: Quantitative research was carried out to test the research's hypotheses: collecting data directly from 215 customers of the modern retail channels in Ho Chi Minh city, screening and filtering junk information from the collected data, and conducting regression analysis using software SPSS 22.0. Findings are discussed to propose managerial implications.

\section{Research scale}

Based on the theoretical basis from previous studies, this study proposes 7 structural concepts in the model and 33 measurement items (Table 1) designed following the 5-point Likert scale (1: Strongly Disagree, 2: Disagree, 3: Neutral, 4: Agree, 5: Strongly Agree)

\begin{tabular}{|c|c|c|c|c|}
\hline Or & Constructs & No of items & Code & Sources \\
\hline 1 & Personality traits & 4 & PT & $\begin{array}{l}\text { (Elfergany \& Adl, 2020); (Singh et al., 2020); } \\
\text { (Smith,2020); (Adjei \& Clark, 2010) }\end{array}$ \\
\hline 2 & Perceived value & 7 & PV & $\begin{array}{l}\text { (Yang \& Peterson, 2004); (Terblanche, 2018); } \\
\text { (Bloemer \& Odekerken-Schröder, 2002); (Hasan et } \\
\text { al. 2014). }\end{array}$ \\
\hline 3 & Customer trust & 4 & CT & (Hasan et al. 2014); (Singh \& Jain, 2015). \\
\hline 4 & $\begin{array}{l}\text { Customer } \\
\text { commitment }\end{array}$ & 4 & $\mathrm{CC}$ & (Thaichon \& Jebarajakirthy, 2015). \\
\hline 5 & Service quality & 6 & $\mathrm{SQ}$ & $\begin{array}{l}\text { (Alam \& Noor, 2020).; } \\
\text { (Sivapalan \& Jebarajakirthy, 2017). }\end{array}$ \\
\hline 6 & Switching Cost & 4 & SC & (Burnham et al. 2003); Aydin et al. (2005) \\
\hline 7 & Customer loyalty & 4 & $\mathrm{CL}$ & $\begin{array}{l}\text { (Lee et al. 2007).; (Alam \& Noor, 2020); (Nyadzayo } \\
\text { \& Khajehzadeh, 2016). }\end{array}$ \\
\hline Total & 7 & 33 & & \\
\hline
\end{tabular}

Table 1: Summary of measurement scales

(Source: Synthetic authors)

\section{Sample and respondents}

This research used the quota non-probability sampling technique. Survey participants are customers who went shopping at convenience stores, mini-marts and others made purchase by means of online shopping via the supermarkets' websites from March to April 2020, the period when Vietnam implemented social distance due to Covid - 19. The survey was conducted in 4 central districts with high population densities and a large number of stores of the modern retail channels in Ho Chi Minh city. The recommended sample size used in this research is 5: 1 (Hair et al., 1998).

\section{Data collection process}

The survey is designed in both paper and digital formats. The data collection is carried out in two formats: 130 paper forms collected directly from customers who went shopping at convenience stores and mini-marts, 110 online survey forms collected via google form for online shopping customers. The total number of forms collected is 240. After screening and processing the data, there are 25 invalid forms (i.e., use the same answer for different questions, leave answers empty). Therefore, the official data for inclusion in the analysis to meet the research objective is 215 forms.

\section{RESULTS}

The raw data from 215 answered forms was input into the statistical analysis application SPSS 22.0 for processing and screening before analyzing and finding the applicable hypotheses. Characteristics of the research samples are described in detail as follows:

\begin{tabular}{|l|l|l|l|l|l|}
\hline Age & Freq. & $\%$ & Occupation & Freq. & $\%$ \\
\hline$<20$ & 68 & 32 & Students & 128 & 60 \\
\hline $20-35$ years & 104 & 48 & Officers & 43 & 20 \\
\hline $36-50$ years & 38 & 18 & Workers & 20 & 9 \\
\hline$>50$ years & 5 & 2 & Housewives & 20 & 9 \\
\hline$<20$ & 68 & 32 & Others & 2 & 2 \\
\hline Income & Freq. & $\%$ & Frequency/week & Freq. & $\%$ \\
\hline$<5$ million VND & 128 & 50 & Once & 3 & 1.4 \\
\hline $5-10$ million VND & 72 & 34 & $2-3$ times & 47 & 21.9 \\
\hline $10<-20$ million VND & 32 & 15 & $4-5$ times & 97 & 45.1 \\
\hline$>20$ million VND & 3 & 1 & $>5$ times & 68 & 31.6 \\
\hline
\end{tabular}

Table 2: Sample demographic characteristics

Source: Authors calculated from SPSS 22.0 software 
Among the survey participants, there are 130 female clients, accounting for $60 \%$, and 85 male clients, accounting for $40 \%$ of the respondents. The highlight of the survey sample is that the proportion of young customers (under 35 years old) accounting for $80 \%$ of the total number of customers surveyed, this shows that young customers prefer shopping in modern retail channels to shopping in traditional markets.

\section{Evaluation of the reliability and validity of the structure in the study}

The author analyzed the reliability of the scale using Cronbach's Alpha statistical method. Cronbach's Alpha coefficients were used to eliminate invalid variables.

Verification of the reliability of the scale shows that the research concepts "perceived value, trust, service quality, personality traits, commitment, switching cost, and customer loyalty" are all reliable. All scales have Cronbach's alpha coefficients greater than 0.6 and the total variable correlation coefficients greater than 0.3 (Hair et al., 1998)., thus we conclude that the scales meet the standards and have statistical significance. Particularly, the concept "Commitment" has the observed variable CC6 with the total variable correlation coefficient smaller than 0.3 and if removing this observed variable, the Cronbach's Alpha coefficient of the total variable will increase. To ensure the reliability of the research, this observed variable CC6 was removed from the model. After removing the variable CC6, the CC factor group was analyzed again and it showed that Cronbach's Alpha coefficient increased from 0,801 to 0.835 and the reliability of the remaining 5 observed variables CC1, CC2, CC3, CC4 and CC5 also increased.

Next, exploratory factor analysis EFA is performed to determine the convergent value of the conceptual structures in the proposed research model.

Verification of the convergence of the factors show that the indexes in the EFA analysis satisfy the following conditions: The $\mathrm{KMO}$ value of the group of independent variables is 0.856 and the group of the dependent variable is 0.801 (condition: large 0 . 5 and less than 1) from which factor analysis is appropriate, Bartlett's Sig value of both independent and dependent variables is 0 , less than the significance of alpha $5 \%$, showing that the observed variables have correlated with each other in the whole. The eigenvalue coefficient of the independent variable group is 1.267 and the dependent variable group is 2.725 , both of which are greater than 1, the extracted factors have good information summary significance, The total variance extracted equal to that of the independent variable group is 58.829 and the dependent variable group is 68.126 (>50\%), this shows that 5 independent factors extracted are explained $58.829 \%$ variation of observed data and 1 extracted dependent factor is explained $68.126 \%$ variation of observed data. Concluding that the data is meaningful for performing further analysis.

\section{Analysis of multivariate regression equations}

Consider correlation relationships between the dependent variable with each independent variable through Pearson correlation analysis. If the correlation coefficient between the dependent variable and the independent variable is large, it proves that there is a relationship between them, and regression analysis is appropriate. Conversely, if the independent variables also have large correlation coefficients, there can be multicollinearity phenomenon in the regression model under consideration.

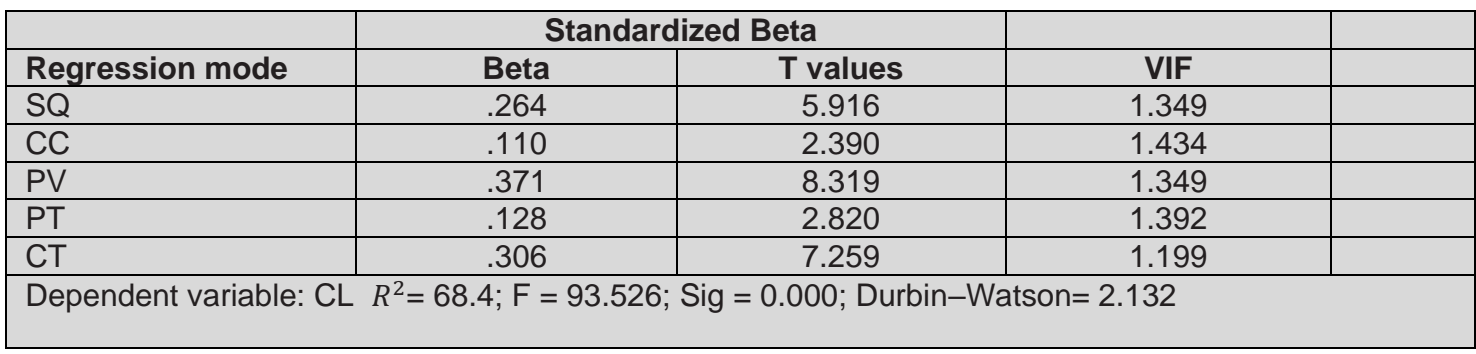

Table 3: Results of predictive model after regression analysis

Source: Authors calculated from SPSS 22.0 software

The results in Table 3 show that the multicollinearity measurement: magnification coefficient VIF of the variables is small (the largest VIF $=1.434<2$ ). This model is small, with no significant effect on the regression results.

The Adjusted R Square shows the degree (\%) of the variation of the dependent variable explained by the independent variable. Looking at Table 3 , the regression results show $68.4 \%$ of the Model 1 means that the variation of $\mathrm{CL}$ is explained by the variation of 5 factors (SQ, CC, PV, PT, CT), the rest $31.6 \%$ is explained by other factors. The Durbin-Watson value is 2.132 in range $(1,3)$, so the model has no autocorrelation phenomenon. The ANOVA analysis table shows that the value $F=93,526$ and significant level sig $=0.000$ (sig $\leq 0.05$ ) has significant regression model meaning consistent with collected data and variables they are both statistically significant with $5 \%$ significance.

The results in Table 3 also shows that all path coefficients between the independent and dependent variables are significant and the influence of 5 independent variables on the dependent variable and the importance of each independent variables in the model.

\section{Analysis of the moderating impact of switching costs}

SC's interactions on relationship between components include $\mathrm{PV}$ * $\mathrm{SC}$; $C T$ * SC; $\mathrm{SQ}$ * SC and endogenous structure of $C L$ was examined and reported through Table 4. 


\begin{tabular}{|l|l|l|l|l|l|l|}
\hline & $\begin{array}{l}\text { Original } \\
\text { weight }\end{array}$ & $\begin{array}{l}\mathbf{P} \\
\text { Values }\end{array}$ & $\boldsymbol{f}^{2}$ & $\boldsymbol{R}^{\mathbf{2}}$ & Hypothesis & Conclusion \\
\hline $\mathrm{CT}^{*} \mathrm{SC} \rightarrow \mathrm{CL}$ & $0.198^{* *}$ & 0.002 & 0.064 & 0.531 & $\mathrm{H} 7$ & Accepted \\
\hline $\mathrm{PV}{ }^{*} \mathrm{SC} \rightarrow \mathrm{CL}$ & $0.044^{\text {ns }}$ & 0.489 & 0.064 & 0.442 & $\mathrm{H} 6$ & Rejected \\
\hline $\mathrm{SQ}{ }^{*} \mathrm{SC} \rightarrow \mathrm{CL}$ & $0.025^{\text {ns }}$ & 0.660 & 0.058 & 0.360 & $\mathrm{H} 8$ & Rejected \\
\hline${ }^{*}: \mathrm{p}<0.1 ;{ }^{* *}: \mathrm{p}<0.05 ;{ }^{* *}: \mathrm{p}<0.001 ;$ ns: not statistical significance \\
\hline
\end{tabular}

Table 4: Test results of moderating impact of switching costs

Source: Authors calculated from SPSS 22.0 software

Hypothesis $\mathrm{H} 7$ is accepted with $95 \%$ confidence when SC positively affects the relationship between CT and CL $(\beta=0.198$; $\mathrm{p}<0.05)$ and the $\mathrm{f} 2$ illustrates small impact on the relationship of the $\mathrm{CT}^{*} \mathrm{SC}$ and $\mathrm{CL}$ ( $\mathrm{f} 2=0.064$ ), with hypothesis $\mathrm{H} 6$ and $\mathrm{H} 8$ are rejected due to the confidence level is lower than $90 \%(\beta=0.044$ and $\beta=0.025 ; p>0.1$ ) so SC has no impact on the relationship between $\mathrm{PV}$ and $\mathrm{CL}$ and $\mathrm{SQ}$ on $\mathrm{CL}$.

\section{Theoretical and Managerial Implications}

\subsection{Theoretical implications}

Customer loyalty has always attracted the attention of scholars due to its clear meaning and the sustainable value it brings to the organization. In the context of the Covid-19 pandemic, there are "shocks to loyalty" in the retail channels (Mckinsey.com 2020) and the price sensitivity of consumers changes (Deloite 2020; Sirohi et al. 1998). This study examines two main issues: the degree to which the factors affect customer loyalty in a modern retail channels and then the relationship between loyalty, and how the client's membership and the influencing factors will be influenced by the switching costs in the context of Covid-19 pandemic in Vietnam.

The first goal is to measure the influence of factors on customer loyalty to a modern retail channels in the context of Covid-19 pandemic in Vietnam. The results from the model show that all 5 factors positively affect loyalty with different degrees which are perceived value, customer trust, service quality, personality traits and customer commitment. Among them, perceived value has the strongest influence on customer loyalty $(\mathrm{H} 1)$. This result is consistent with previous research of (El-Adly \& Eid, 2016; Tu \& Chih, 2011) in the same modern retail. This shows that the perceived value of the customer plays the most important role in maintaining loyalty. In addition, customer trust also plays a significant role in maintaining loyalty $(\mathrm{H} 2)$. This research has contributed to the previous research (Zhang \& Li,
2019); (Rico et al. 2019) when pointing out that trust contributes to customer loyalty to the modern retail channels. Similarly, the research results from the model show that service quality also significantly affects customer loyalty $(\mathrm{H} 3)$ and is corroborated by Kaura et al. (2015) in the same field of study. However, this study result is inconsistent with the research conclusions of Rico et al. 2019 in which service quality does not affect customer loyalty. This opposite result is explained when the quality of service is not provided by the modern retailer itself but is supported by a business; thus, the quality of service provided cannot be controlled.

The other two factors of the model are the personality traits (H4) and commitment (H5) are further explored as factors affecting customer loyalty to a lower level. The results of this study $(\mathrm{H} 4)$ are supported by recent research (Elfergany \& Adl, 2020). An important finding of this study is that customer commitment weakly affects loyalty when placed in the context of Covid -19 pandemic. The results of this study are different from previous studies when the commitment was the main influencing factor driving customer loyalty (Richard \& Zhang, 2012; Huang et al. 2007). This can be explained through Maslow's pyramid of needs when safety is an individual's basic need, so every commitment seems weaker and easier to break down to ensure human survival needs.

The results of the study from the empirical model shed light on the second objective when it shows that there is no moderation between the switching costs on the relationship between perceived value $(\mathrm{H} 6)$ and service quality $(\mathrm{H} 8)$ with customer loyalty. The only accepted hypothesis $\mathrm{H} 7$ represents switching costs with moderation on the relationship between customer trust and loyalty. The conclusion of this study is consistent with previous research results of El-Manstrly (2016). However, the difference of this study is that switching costs only have a weak effect on the relationship between customer trust and loyalty. Hence, the consumers will not completely trade off their safety for loyalty to a modern retailer because of the switching costs. They will stick to a retailer that gives them more confidence when shopping safely. 


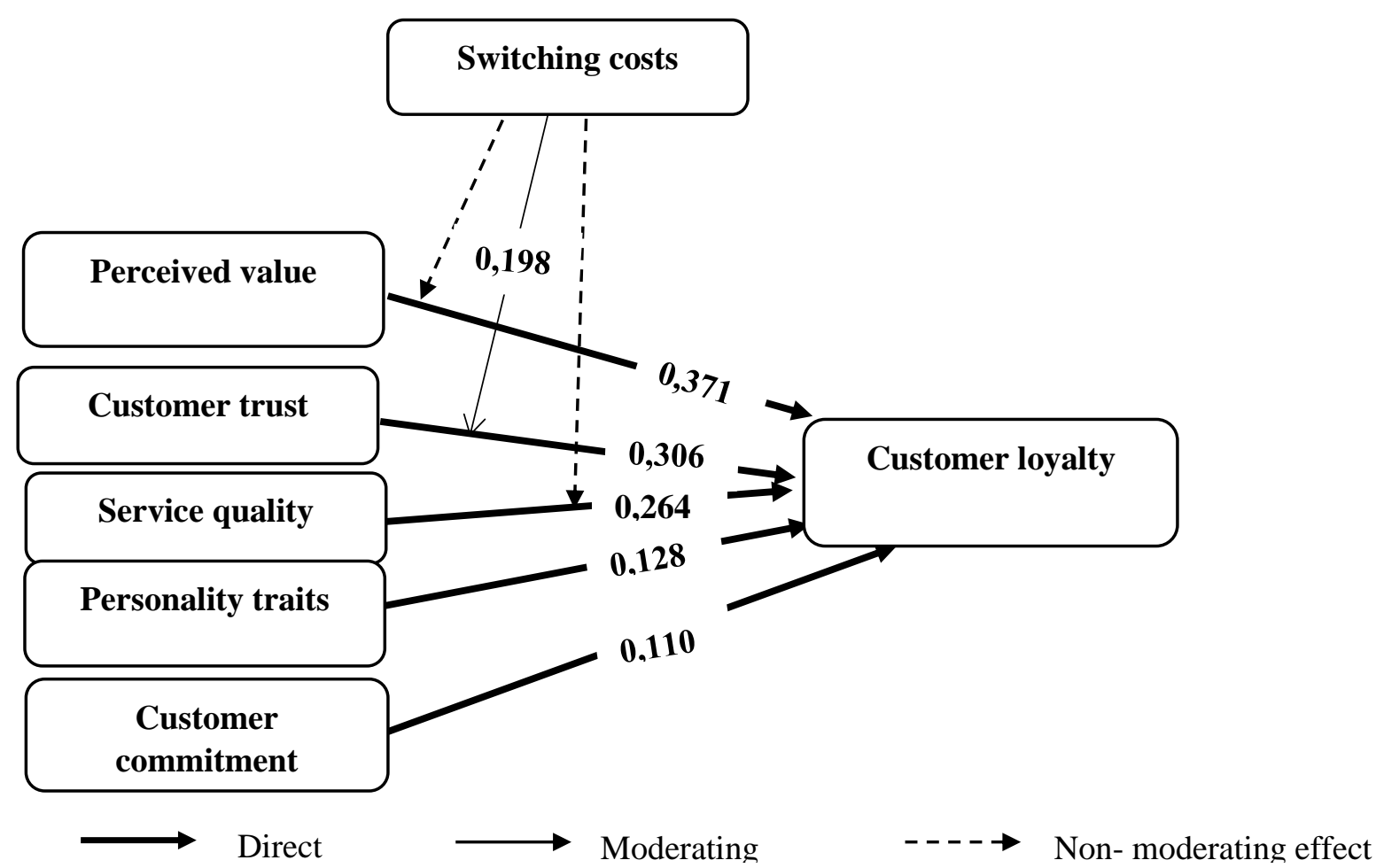

Figure 2: Study results

\subsection{Managerial implications}

The research results mean that while Covid-19 pandemic in the world still not under controlled, the issue that consumers are concerned about is the safety when shopping. Therefore, in order to retain customers and maintain their loyalty, modern retailers must create a sense of safety and peace of mind for customers when shopping. We have seen some consumer aversion to physical contact in store environments as well as focusing more on convenience, speed, and digital experience. This means investing in the appropriate digital technologies to create the consumer experience, for example Scan and Go technology designed to make the shopping experience simpler, faster and more convenient for consumers instead of going through a lengthy process of scanning all items at the end of a visit. Customers can scan each item as they place it in their cart and pay for the purchase through means of no touching.

Next to address this "loyalty shock", modern retailers should identify which stores are being affected when customers switch to other stores. Modern retailers will find ways to better communicate the efforts they are making to build customer trust and improve service quality to broaden their support. Thus, it is a little easier for consumers to forgive and can help attract those customers back. Specifically, they will need to focus on ensuring transparency and flexibility such as allowing consumers to track their deliveries or choose the suitable delivery times.

In addition, those modern retail chain managers can enhance customer loyalty with different strategies to attract and retain customers with different identities (Adjei \& Clark, 2010). Statistical survey sample of this study with $80 \%$ of young customers (aged 35 and under) shows that there are often customers looking for diversity and creativity which create managers who can enhance loyalty in behavior by regularly providing new information about products and services, or changing the way in-store displays and the new and interesting things the store is implementing. At the same time, personality data can be collected through the loyalty card program (Smith,
2020) for the purpose of implementing sales programs in accordance with the personality traits.

Finally, as consumers'price sensitivity and notions of brand attractiveness have changed in the aftermath of the Covid-19 pandemic (Deloite (2020), chain managers of modern retailers need to sustain customer loyalty and minimize store switching behavior by building trust between customers and salespeople while providing information about store services and monetary and non-monetary benefits such as special treatment, custom services, discounts and recognition benefits on its official information pages to improve the transparency of the sale chain. Therefore, modern retail has the effect of strengthening consumer confidence, gradually improving customers' trust with modern retail stores and brands with the quality of services provided and appropriate communication programs.

\subsection{Limitation and future research direction}

This study does provide some implications for customer loyalty to modern retail channels in the context of Covid -19 pandemic. However, this study has some limitations as follows. First, the study was based on the overall customer personality traits, but not yet answering the questions to measure the impact of each customer personality traits on the customer loyalty. Therefore, a more detailed study of the current results should be conducted in the future to better understanding of customer personality traits. Second, the survey sample of the study does not distinguish domestic and foreign modern retailers to examine the difference leading to customer loyalty. Future study needs to collect data with broader and more diverse patterns and contexts, and there should be a comparison between domestic and foreign retailers. From that research, domestic retailers in developing countries have appropriate business strategies to maintain and enhance their loyalty in the context of competition and market penetration as well as the $M \& A$ trend of leading retail groups in the world. 


\section{References}

[1] Adjei, M. T., \& Clark, M. N. (2010). Relationship marketing in A B2C context: The moderating role of personality traits. Journal of Retailing and Consumer Services, 17(1), 73-79. doi: 10.1016/j.jretconser.2009.10.001

[2] Akbar, M. M. (2013). Three competing models on customer loyalty in the context of mobile subscribers. International Journal of Marketing Studies, 5(4), 42. doi: 10.5539/ijms.v5n4p42

[3] Alam, M. M. D., \& Noor, N. A. M. (2020). The Relationship Between Service Quality, Corporate Image, and Customer Loyalty of Generation Y: An Application of SOR Paradigm in the Context of Superstores in Bangladesh. SAGE Open, 10(2), 2158244020924405. doi: 10.1177/2158244020924405

[4] Lipsman, A. (2019). Global Ecommerce 2019 report: Ecommerce continues strong gains amid Global Economic Uncertainty. Retrieved june 27, 2019, from https://www.emarketer.com/content/global-ecommerce-2019.

[5] Aydin, S., Özer, G., \& Arasil, Ö. (2005). Customer loyalty and the effect of switching costs as a moderator variable. Marketing intelligence \& planning. doi: 10.1108/02634500510577492

[6] Baek, W. Y., Kim, K. A., Kim, D. H., \& Byon, K. K. (2020). The Impacts of the Perceived Golf Course Brand Globalness on Customer Loyalty through Multidimensional Perceived Values. Sustainability, 12(3), 978. doi: 10.3390/su12030978

[7] Baumgartner, H. (2002). Toward a personology of the consumer. Journal of Consumer Research, 29(2), 286-292. doi: $10.1086 / 341578$

[8] Bloemer, J. M. M., \& Odekerken-Schröder, G. J. (2002). Store satisfaction and store loyalty explained by customer-and store related factors.

[9] Bobâlcă, C. (2014). Determinants of Customer Loyalty, A Theoretical Approach. Journal of International Scientific Publications, 8.

[10] Burnham, T. A., Frels, J. K., \& Mahajan, V. (2003). Consumer switching costs: a typology, antecedents, and consequences. Journal of the Academy of marketing Science, 31(2), 109-126. doi: 10.1177/0092070302250897

[11] Casidy, R., \& Wymer, W. (2016). A risk worth taking: Perceived risk as moderator of satisfaction, loyalty, and willingness-to-pay premium price. Journal of Retailing and Consumer Services, 32, 189-197. doi: 10.1016/j.jretconser.2016.06.014

[12] Cervone, D., \& Pervin, L. A. (2015). Personality: Theory and research. John Wiley \& Sons.

[13] Cossío-Silva, F. J., Revilla-Camacho, M. Á., Vega-Vázquez, M., \& Palacios-Florencio, B. (2016). Value co-creation and customer loyalty. Journal of Business Research, 69(5), 1621-1625. doi: 10.1016/j.jbusres.2015.10.028

[14] Curran, J. M., Varki, S., \& Rosen, D. E. (2010). Loyalty and its antecedents: are the relationships static? Journal of Relationship Marketing, 9(4), 179-199. doi: 10.1080/15332667.2010.522469

[15] De Wulf, K., Odekerken-Schröder, G., \& lacobucci, D. (2001). Investments in consumer relationships: A cross-country and cross-industry exploration. Journal of marketing, 65(4), 33-50. doi: 10.1509/jmkg.65.4.33.18386

[16] Deloite (2020). Retail in Vietnam report | An accelerated shift towards Omni channel retailing

[17] Dick, A. S., \& Basu, K. (1994). Customer loyalty: toward an integrated conceptual framework. Journal of the academy of marketing science, 22(2), 99-113. doi: $10.1177 / 0092070394222001$

[18] El-Adly, M. I., \& Eid, R. (2016). An empirical study of the relationship between shopping environment, customer perceived value, satisfaction, and loyalty in the UAE malls context. Journal of Retailing and Consumer Services, 31, 217-227. doi: 10.1016/j.jretconser.2016.04.002

[19] Elfergany, A. K., \& Adl, A. (2020). Identification of Telecom Volatile Customers Using a Particle Swarm Optimized K-Means Clustering on Their Personality Traits Analysis. International Journal of Service Science, Management, Engineering, and Technology (IJSSMET), 11(2), 1-15. doi: 10.4018/ijssmet.2020040101

[20] El-Manstrly, D. (2016). Enhancing customer loyalty: critical switching cost factors. Journal of Service Management.

[21] Esenyel, I., \& Girgen, M. (2019). Customer interactions on social media and their impact on trust and loyalty: the moderating role of product learning. Management Science Letters, 9(9), 14971506. . doi: 10.5267/j.msl.2019.5.003

[22] Ethan Cramer-Flood (2020). Global Ecommerce 2020 report: Ecommerce Decelerates amid Global Retail Contraction but Remains a Bright Spot. Retrieved June 22, 2020, from https://www.emarketer.com/content/global-ecommerce-2020.

[23] Fida, B. A., Ahmed, U., Al-Balushi, Y., \& Singh, D. (2020). Impact of Service Quality on Customer Loyalty and Customer Satisfaction in Islamic Banks in the Sultanate of Oman. SAGE Open, 10(2), $2158244020919517 . \quad$ doi: $10.1177 / 2158244020919517$

[24] Fornell, C. (1992). A national customer satisfaction barometer: The Swedish experience. Journal of marketing, 56(1), 6-21. doi: $10.1177 / 002224299205600103$

[25] Gruen, T. W., Summers, J. O., \& Acito, F. (2000). Relationship marketing activities, commitment, and membership behaviors in professional associations. Journal of marketing, 64(3), 34-49. doi: $10.1509 / j m k g .64 .3 .34 .18030$

[26] HAIR JUNIOR, J. F., Black, W. C., Babin, B. J., Anderson, R. E., \& Tatham, R. L. (1998). Multivariate data analysis. New Jersey.

[27] Harazneh, I., Adaileh, M., Thbeitat, A., Afaneh, S., Khanfar, S., Harasis, A., \& Elrehail, H. (2020). The impact of quality of services and satisfaction on customer loyalty: The moderate role of switching costs. Management Science Letters, 10(8), 18431856. doi: $10.5267 /$ J.msl.2019.12.034

[28] Hidayanti, I., \& Nuryakin, N. F. (2018). A study on brand commitment and brand trust towards brand loyalty of branded laptop in Indonesia. Journal of Business and Retail Management Research, 12(3). doi: 10.24052/jbrmr/v12is03/art-25

[29] Huang, L. T., Cheng, T. C., \& Farn, C. K. (2007). The mediating effect of commitment on customer loyalty towards e-brokerages: An enhanced investment model. Total Quality Management \& Business Excellence, 18(7), 751-770. doi: 10.1080/14783360701349765

[30] IMF (2020). World Economic Outlook report: chapter 1: The Great lockdown.

[31] Jaiswal, A. K., \& Niraj, R. (2011). Examining mediating role of attitudinal loyalty and nonlinear effects in satisfaction-behavioral intentions relationship. Journal of Services Marketing. doi: 10.1108/08876041111129155

[32] Jamrozy, U., \& Lawonk, K. (2017). The multiple dimensions of consumption values in ecotourism. International Journal of Culture, Tourism and Hospitality Research. doi: 10.1108/ijcthr09-2015-0114

[33] Kandampully, J., Zhang, T. C., \& Bilgihan, A. (2015). Customer loyalty: a review and future directions with a special focus on the hospitality industry. International Journal of Contemporary Hospitality Management. doi: 10.1108/ijchm-03-2014-0151

[34] Kaura, V., Prasad, C. S. D., \& Sharma, S. (2015). Service quality, service convenience, price and fairness, customer loyalty, and the mediating role of customer satisfaction. International Journal of Bank Marketing. doi: 10.1108/ijbm-04-2014-0048

[35] Kim, S. H., Kim, M., \& Holland, S. (2018). How customer personality traits influence brand loyalty in the coffee shop industry: The moderating role of business types. International journal of hospitality \& tourism administration, 19(3), 311-335. doi: $10.1080 / 15256480.2017 .1324340$

[36] Lee, J., Lee, J., \& Feick, L. (2001). The impact of switching costs on the customer satisfaction-loyalty link: mobile phone service in France. Journal of services marketing. doi: 10.1108/08876040110381463

[37] Lee, K. Y., Huang, H. L., \& Hsu, Y. C. (2007). Trust, satisfaction and commitment-on loyalty to international retail service brands. Asia Pacific Management Review, 12(3), 161-169.

[38] Melewar, T. C., Foroudi, P., Gupta, S., Kitchen, P. J., \& Foroudi, 
M. M. (2017). Integrating identity, strategy and communications for trust, loyalty and commitment. European Journal of Marketing. doi: 10.1108/ejm-08-2015-0616

[39] Menidjel, C., Bilgihan, A., \& Benhabib, A. (2020). Exploring the impact of personality traits on perceived relationship investment, relationship quality, and loyalty in the retail industry. The International Review of Retail, Distribution and Consumer Research, 1-24. doi: 10.1080/09593969.2020.1781228

[40] Morgan, R. M., \& Hunt, S. D. (1994). The commitment-trust theory of relationship marketing. Journal of marketing, 58(3), 2038. doi: $10.2307 / 1252308$

[41] Nyadzayo, M. W., \& Khajehzadeh, S. (2016). The antecedents of customer loyalty: A moderated mediation model of customer relationship management quality and brand image. Journal of Retailing and Consumer Services, 30, 262-270. doi: 10.1016/j.jretconser.2016.02.002

[42] Ng, S., David, M. E., \& Dagger, T. S. (2011). Generating positive word-of-mouth in the service experience. Managing Service Quality: An International Journal. doi: $10.1108 / 09604521111113438$

[43] Obi, H. (2020). KNOWLEDGE MANAGEMENT: A SPUR FOR PERFORMANCE OF DEPOSIT MONEY BANKS IN RIVER STATE. Journal of Marketing, $5,1$.

[44] Oliver, R. L. (1999). Whence consumer loyalty? Journal of marketing, 63(4_suppl1), 33-44. $10.1177 / 00222429990634 \mathrm{~s} 105$

[45] Orel, F. D., \& Kara, A. (2014). Supermarket self-checkout service quality, customer satisfaction, and loyalty: Empirical evidence from an emerging market. Journal of Retailing and Consumer Services, 21(2), 118-129. doi: 10.1016/j.jretconser.2013.07.002

[46] Othman, A. K., Hassan, L. F. A., Ibrahim, M. A. M., Saripin, M. S., Sapuan, N. S. A., \& Roslan, Z. N. (2020). Factors that influence customer loyalty in using e-commerce. Journal of Islamic Management Studies, 2(2), 43-58.

[47] Rahi, S., \& Ghani, M. (2016). Internet banking, customer perceived value and loyalty: the role of switching costs. J Account Mark, 5(4), 188

[48] Ramadhan, L., \& Yolanda Masnita Siagian, M. M. Impact of Customer Perceived Value on Loyalty: In Context Crm. doi: 10.31227/osf.io/mu6fb

[49] Richard, J. E., \& Zhang, A. (2012). Corporate image, loyalty, and commitment in the consumer travel industry. Journal of Marketing Management, 28(5-6), 568-593. doi: $10.1080 / 0267257 \times .2010 .549195$

[50] Rico, M. T., Wahyoedi, S., \& Purnama, E. D. (2019, May). The Effects of Trust, Service Quality and Perceived Value on Satisfaction and Their Impact on Loyalty. In International Conference on Entrepreneurship and Business Management (ICEBM) Untar (pp. 325-330). doi: 10.5220/0008492603250330

[51] Rust, R. T., Lemon, K. N., \& Zeithaml, V. A. (2004). Return on marketing: Using customer equity to focus marketing strategy. Journal of marketing, 68(1), 109-127. doi: 10.1509/jmkg.68.1.109.24030

[52] Saeed, K., \& Siddiqui, K. (2016). Influence of Customer's LoyaltySatisfaction Link on Services Usage. Journal of Marketing Management and Consumer Behavior, 1(2), 22-31.

[53] Sharma, N., \& Patterson, P. G. (2000). Switching costs, alternative attractiveness and experience as moderators of relationship commitment in professional, consumer services. International journal of service industry management. doi: 10.1108/09564230010360182

[54] Singh, D., Bajpai, N., \& Kulshreshtha, K. (2020). Brand Experience-Brand Love Relationship for Indian Hypermarket Brands: The Moderating Role of Customer Personality Traits. Journal of Relationship Marketing, 1-22. doi: 10.1080/15332667.2020.1715179

[55] Singh, R., \& Rosengren, S. (2020). Why do online grocery shoppers switch? An empirical investigation of drivers of switching in online grocery. Journal of Retailing and Consumer Services, 53 ,
0.1016/j.jretconser.2019.101962Singh, V., \& Jain, A. (2015). Consumer trust in retail: Development of a multiple item scale. Journal of Economics, Business and Management, 3(10), 971-976. doi: 10.7763/joebm.2015.v3.318

[56] Sirohi, N., McLaughlin, E. W., \& Wittink, D. R. (1998). A model of consumer perceptions and store loyalty intentions for a supermarket retailer. Journal of retailing, 74(2), 223-245. doi: 10.1016/s0022-4359(99)80094-3

[57] Sivapalan, A., \& Jebarajakirthy, C. (2017). An application of retailing service quality practices influencing customer loyalty toward retailers. Marketing Intelligence \& Planning. doi: 10.1108/mip-09-2016-0178

[58] Smith, T. A. (2020). The role of customer personality in satisfaction, attitude-to-brand and loyalty in mobile services. Spanish Journal of Marketing-ESIC. doi: 10.1108/sjme06-2019-0036

[59] Song, H., Wang, J., \& Han, H. (2019). Effect of image, satisfaction, trust, love, and respect on loyalty formation for name-brand coffee shops. International Journal of Hospitality Management, 79, 50-59. doi: 10.1016/j.ijhm.2018.12.011

[60] Stanisavljević, M. (2017). Does customer loyalty depend on corporate social responsibility? Naše gospodarstvo/Our economy, 63(1), 38-46. doi: 10.1515/ngoe-2017-0004

[61] Suhartanto, D. (2019). Predicting behavioural intention toward Islamic bank: a multi-group analysis approach. Journal of Islamic Marketing. doi: 10.1108/jima-02-2018-0041

[62] Taylor, S. A., Celuch, K., \& Goodwin, S. (2004). The importance of brand equity to customer loyalty. Journal of product \& brand management. doi: 10.1108/10610420410546934

[63] Terblanche, N. S. (2018). Revisiting the supermarket in-store customer shopping experience. Journal of Retailing and Consumer Services, 40, 48-59. doi: 10.1016/j.jretconser.2017.09.004

[64] Tu, Y. T., \& Chih, H. C. (2011). The effect of service quality, customer perceived value and satisfaction on loyalty. Journal of Economics and Behavioral Studies, 3(3), 198-212. doi: 10.22610/jebs.v3i3.273

[65] Thaichon, P., \& Jebarajakirthy, C. (2015). Evaluating specific service quality aspects which impact on customers' behavioural loyalty in high-tech internet services. Asia Pacific Journal of Marketing and Logistics. doi: 10.1108/apjml-02-2015-0027

[66] Thakur, R. (2016). Understanding customer engagement and loyalty: a case of mobile devices for shopping. Journal of Retailing and consumer Services, 32, 151-163. doi: 10.1016/j.jretconser.2016.06.004

[67] Vázquez-Carrasco, R., \& Foxall, G. R. (2006). Influence of personality traits on satisfaction, perception of relational benefits, and loyalty in a personal service context. Journal of Retailing and Consumer Services, 13(3), 205-219. doi: 10.1016/j.jretconser.2005.08.006

[68] World bank (2020). Global Economic Prospects report: chapter 1: Pandemic, recession: The global economy in crisis doi: 10.1596/978-1-4648-1553-9 ch1

[69] Yang, Z., \& Peterson, R. T. (2004). Customer perceived value, satisfaction, and loyalty: The role of switching costs. Psychology \& marketing, 21(10), 799-822. doi: 10.1002/mar.20030

[70] Yoon, S., \& Park, J. E. (2018). Tests of in-store experience and socially embedded measures as predictors of retail store loyalty. Journal of Retailing and Consumer Services, 45, 111119. doi: 10.1016/j.jretconser.2018.08.010

[71] Zhang, C. B., \& Li, Y. N. (2019). How social media usage influences B2B customer loyalty: roles of trust and purchase risk. Journal of Business \& Industrial Marketing. doi: 10.1108/jbim-07-2018-0211

[72] Zhong, Y., \& Moon, H. C. (2020). What Drives Customer Satisfaction, Loyalty, and Happiness in Fast-Food Restaurants in China? Perceived Price, Service Quality, Food Quality, Physical Environment Quality, and the Moderating Role of Gender. Foods, 9(4), 460. doi: 10.3390/foods 9040460 